\title{
The FLN and the role of women during the war
}

The universally held image of women during the Algerian War is that, made famous by Frantz Fanon and Pontecorvo's classic film The Battle of Algiers, of Muslim women as heroic resistance fighters. However, this enduring symbol of 'Third World' women confronting the might of colonial armies reflects more the propaganda success of the FLN in manipulating the representation of Algerian women than any real or enduring transformation of their position or rights. For the majority of FLN leaders the 'woman question' did not constitute a significant issue: the immediate life-and-death business of waging war and of national survival was thought to be far too urgent a matter to allow energies to be diverted in this direction and women's equality it was thought would be almost automatically achieved through independence and liberation from colonialism. ${ }^{1}$ However, the FLN was forced during the course of the war to take a position on women for two reasons: firstly, women gradually assumed a de facto role in the conflict, playing a major part in urban networks and the maquis as gun and bomb carriers, messengers, fund collectors, nurses, look-outs, cooks and doctors. Inevitably, as often in time of war, such activities presented a challenge to traditional concepts of segregation of the sexes, gender and male dominance. Secondly, the FLN was perfectly aware that a key intention of the French military in undertaking an emancipation agenda was to place the nationalists on the spot, since it was calculated that they would be unwilling or unable to respond by adopting their own progressive reform, while direct opposition to French liberation from custom and patriarchy would expose them in the UN and among international opinion as reactionaries. How the FLN responded to this dual challenge during the war was to set the scene, as will be shown in chapter 11, for the post-independence political marginalisation of women and the long-term failure of a reform agenda. 


\section{The ad hoc mobilisation of women}

The most interesting and dynamic phase of women's direct engagement in the war came during 1955-57, a more open and experimental period that carried the promise or potential for a real transformation in gender roles, but which was suddenly 'closed down' by the FLN leadership from late 1957 onwards. During this initial phase many thousands of women first became engaged in various levels of direct action as fighters, nurses, ancillaries and providers of logistic support to the ALN. This mobilisation did not occur as the result of a central policy decision but emerged in a piecemeal or ad hoc way in response to the situation that urban and rural male combatants found themselves in, for example facing a shortage of trained nurses to tend to wounded fighters in make-shift field hospitals. ${ }^{2}$ In general terms the FLN attitude towards women was reactive, a pragmatic and localised response to the direct presence of women who challenged entrenched male misogyny or patriarchy. The ALN commanders of the regions (Wilaya), with weak lines of communication to the external provisional government, often showed considerable autonomy of action and this was reflected in quite different localised attitudes to a female presence in the maquis, from a relatively progressive and more secular or socialist position, to highly traditionalist, religious inspired, patriarchal authoritarianism. But the overall climate within the ALN was conservative, a reflection of the values of the male peasantry, and truly radical officers were very few in number and remained isolated. What glimmering there was of more innovative policies or practices on the ground, as in Wilayas II (Constantinois) and IV (Algiers), ${ }^{3}$ was brought to a halt by the central decision in late 1957 to withdraw women from the maquis to Tunisia and Morocco, and there to reassert a harsh discipline over those who had gained a taste of greater freedom and individual autonomy.

In order to understand the reactions of Algerian males to direct contact with women militants on the ground, it is helpful to divide the latter into two quite different categories, the minority of urban-based and usually better-educated commandos (the fidayate), many of whom later escaped to the maquis, and the tens of thousands of anonymous peasant women 'civilians' in the rural areas (moussebilate) who provided vital support to the moudjabidines (fighters in ALN units). ${ }^{4}$ These two groups will be examined in turn.

\section{The fidayate: the symbol of the urban warrior}

The single most enduring and iconic image associated with the Algerian War is of Muslim women in the terrorist networks who transported 
documents, guns and bombs through the parachutist check-points. Today, in a world in which suicide bombings have become almost commonplace, it is easy to lose sight of the extent to which the detection and arrest of female terrorists from late 1956 onwards caused a shocked or astonished response among both French and international public opinion. ${ }^{5}$ Here were veiled women engaging, according to one's point of view, in horrific acts of indiscriminate and bloody violence or in deeds of heroic bravery that seemed to defy all the stereotypes of Muslim women as cloistered and supine creatures totally lacking in willpower or autonomy. Did the activities of young female bombers in the streets of Algiers mark a turning-point in the assertion of women's power or position in Algerian society?

Firstly, the young women who were carefully selected by Yacef Saadi to assist with his terrorist network in the ZAA were recruited in the main from known and trusted petit-bourgeois or modest nationalist families. ${ }^{6}$ Many had been educated to lycée level, at a time when only one in ten Muslim girls received even primary schooling, and Samia Lakhdari and Zohra Drif were university law students and daughters of Muslim lawyers (cadis). ${ }^{7}$ During the first post-Second World War decade of an organised women's movement most individuals were drawn into militant activity since they had access to the male-dominated universe of political activism by the 'accident' of being located within nationalist family and kin networks (chapter 2) and this pattern continued into the War of Independence. Thus Djamila Bouhired was recruited by her uncle Mustapha Bouhired, an FLN militant, and Louisette and Malika Ighilahriz by their father. ${ }^{8}$ The young fidayate certainly were required to carry out tasks that broke the conventions of 'respectability' and honourable behaviour: dressing in a chic western mode of short skirts and make-up so as to pass easily through parachutist check-points, moving about unescorted in urban space, and making contact alone with unknown males. ${ }^{9}$ However, most of this breaching of strict gender roles was largely on terms decided by males: the fidayate never assumed positions of command, but always obeyed male orders and even in their most perilous exploits were still their adjuncts (Bouhired was initially appointed to Saadi's top-secret cell as a cook). FLN militants, including even fathers, were prepared to tolerate fidayate breaking the rules of segregation under the exceptional conditions of nationalist struggle, a situation that demanded every sacrifice, but there was an assumption that things would return to 'normal' with the end of the war.

It was undoubtedly the case that some fidayate like Zohra Drif were strong-willed women and Yacef Saadi, for example, through constant daily and close work with Drif in restricted safe-houses and dangerous 
missions established a degree of closeness and trust that was unusual compared to the normal relations between unrelated men and women in Algerian society. ${ }^{10}$ But it should be kept in mind that the urban fidayate were very few in number and that most of their actions in breaking through the constraints of conservative gender roles were restricted to a clandestine world that went unobserved by the majority of women. During Saadi's famous secret meetings in Algiers with the ethnologist Germain Tillion, Zohra Drif reverted to the habitual role of the silent and subservient female, serving tea and cakes, taking a back seat and keeping her personal hostile opinion of the ethnologist to herself. ${ }^{11}$

However, the fidayate did come to play an enormously important role in FLN propaganda as heroic fighters and martyrs to the nationalist cause. The trial of the leading women bombers and, in particular, of Djamila Bouhired in July 1957, was an international media sensation and the leading FLN defence lawyer Jacques Vergès was skilled in developing a strategy that used the courtroom as a political space for the indictment of French military violence, torture and abuse of human rights, a monstrous violence that he was able to highlight by the inhumane treatment and rape of FLN women. ${ }^{12}$ Vergès, who later married Bouhired, collaborated with the novelist Georges Arnaud, author of The Wages of Fear, in writing a small booklet, Pour Djamila Boubired, and the heroic exploits of the young terrorist were soon celebrated through an Egyptian film, Djamila l'Algérienne (1958) of Youcef Chacine, and by popular singers across North Africa, such as Ouardia El Djezaïria and Sou'ad Mohamed in Egypt, and Hadja Hamdaouïa in Morocco. ${ }^{13}$

In all six fidayate received the death sentence during the war, and the campaigns by the French left and intellectuals to save them from the guillotine provided further global publicity. In the later stages of the war (1959-62) came the arrest and trial of the photogenic Djamila Boupacha, whose defence was taken up by the feminist lawyer Gisèle Halimi and by Simone de Beauvoir who set up the Comité pour Djamila Boupacha and jointly published Djamila Boupacha, illustrated with photographs and a Picasso portrait. ${ }^{14}$ The young women militants came to symbolise the Algerian cause, particularly for communists, socialists and liberals throughout the world, as well as for many 'Third World' women then engaged in revolutionary or anti-colonial struggle. ${ }^{15}$ The FLN propaganda organisation also distributed to the international media photographs of women soldiers in the maquis, dressed in uniform and displaying the ultimate symbol of manhood, automatic rifles, although in reality the ALN avoided training women as combatants. ${ }^{16}$ The images of female combatants were reinforced by the martyrology of women maquisards who, when outnumbered or captured, had fought to 
the death, like Malika Gaid and Messika Benziza. ${ }^{17}$ The ALN also made use of the image of the martyr to appeal to Algerian women to support the national struggle, as in one tract from mid-1958, 'Algerian women! Listen! Do you not hear the boots of the French occupier clicking on the road? Do you not hear the screams of massacred or tortured Algerian women and men? Do you not hear the proud call of Djamila Bouhired? ... Heroic and martyrised Algeria has its gaze fixed on you'. ${ }^{18}$

The FLN was quite happy to make use of such propaganda since, while to the outside world it carried a strong revolutionary message, the icon of the female soldier and heroine did not necessarily offer a significant challenge to established gender norms. Throughout the Muslim societies of the Middle East and Maghreb there existed a historical and religious tradition that presented famous real or mythical warriors, like the Algerian Kahina, who in times of exceptional danger to the people had assumed the role of men in resisting invaders and tyrants. A key point of reference here was the role model of Zainab, sister of Imam Hussain, who played a supporting role at the Battle of Karbala. A common structure to this topos was that in a world turned upside down by chaos and defeat, in which men themselves had failed to protect the nation and become 'like women', then it was up to women to assume the masculine role of the warrior and saviour. ${ }^{19}$ Afsaneh Najmabadi has noted that the rhetoric of Iranian male nationalists, in 'calling patriotic women manly implied a reassuring restoration of gender order: only men performed such great acts'. ${ }^{20}$ This way of thinking surfaced constantly during the Algerian War, as in the case of a young boy, angry and frustrated by his father's unmanly silence towards an oppressive French authority, who dared berate the very symbol of masculine honour: 'Women are in prison, why not the men?'. ${ }^{21}$ Many moudjabidate internalised the masculine logic of the female warrior: theirs was only a temporary status, not proof of a lasting transformation of gender roles, and with the coming of independence in 1962 they quietly 'demobilised' by withdrawing from public life back into the private, domestic sphere of the home.

\section{The urban moudjabidate in the maquis}

The proactive role of women militants ruffled few feathers among their male comrades in the major towns, since most of the latter were city born and educated and quite used to a degree of mixing or contact with young 'modern' women who went unveiled and followed a European life-style. The situation was very different in the rural hinterland and it was here that the arrival of hundreds of young and educated women 
in the maquis during 1956-57 led to widespread disquiet and hostility in the ALN ranks. ${ }^{22}$ During 1956 the ALN began to recruit qualified nurses or women with medical experience into the maquis, and this flow was increased after May 1956 by lycée and university students who followed the FLN appeal for a boycott of the educational system, and during 1957 by militants who fled Algiers to escape imminent arrest. Many of these educated women were profoundly shocked by the conditions of extreme hardship and backwardness they found in the interior, but in turn many of the army officers and rank-and-file treated them as unwelcome guests, especially as they presented a threat to the traditional gender roles and rigid sexual segregation that reigned in peasant society and in the universe of the male warrior. A high percentage of the ALN force was constituted of illiterate men, simple but tough combatants who were immersed in the misogynist, patriarchal values of traditional rural society, and in whose eyes single, un-chaperoned women presented a kind of scandal and a disturbing sexual temptation to all men. The success of the French army 'complot bleu', by which they led the paranoid ALN leader Amirouche to believe in a plot to send students and urban intellectuals as agents into the maquis, created widespread suspicious towards the self-assertive, educated and often middle-class young women who were now in their midst. ${ }^{23}$ To this was added the distrust of the rough maquisards, the peasantry and clerics towards the city, a place which they associated with the soft living, decadence and sexual dangers of the west. Even Baya Laribi, toughened after a year in the maquis, came to share these perceptions and was hostile to the wave of young women who arrived in the bled in 1957: 'They were well dressed, with red varnished nails, pretty shoes, nicely cut trousers, and wore brassieres'. ${ }^{24}$

ALN officers, faced with this unwanted intrusion, frequently felt that it was the duty of the army to act as a surrogate guardian and to impose draconian regulations on the moudjahidate, particularly their segregated sleeping arrangements. In Wilaya I it was ordered, 'it is forbidden to nurses to introduce themselves and to sleep among the combatants. They must only keep company with civilians and only with women. Brother Mekki Hihi is in charge of the nurses'. ${ }^{25}$ In some regions, notably Wilaya III, women were subjected on arrival to a degrading virginity test, although some strongly resisted this. ${ }^{26} \mathrm{~A}$ circular sent out by a zone council in Wilaya II in late 1958 noted, 'it is formally forbidden for any women to join our ranks; if they should join us, they must be forced back to their place of origin, even if they are captured by the enemy. Those who accompany these women must be punished with the death sentence'. ${ }^{27}$ 
However, some moudjahidine noted that, after an initial shock or surprise, many of those who were hostile or disturbed by the presence of young women gradually came round to accept the valuable role that they played. Yamina Cherrad's experience was quite typical:

The main problem was the refusal by many of the maquisards to accept our presence. There were some who took us for girls who had come to get married; they could not understand that we also wanted to be militants and to work. Some intellectuals took this in a good way. Others were astonished or intrigued. But certain soldiers were scornful, they tried to assert their superiority, their strength in relation to us. Later, with the passing of months, they came to recognise our worth, especially during a skirmish or on operations. $^{28}$

During 1956-57 in areas controlled by more liberal commanders there were signs of a proto-feminist discourse as in Renaissance Algérienne, a publication of Wilaya III. If the 1 November 1954, noted the journal, rang 'the toll bell of colonialism in Algeria, it also marked a new era in the Liberation of women . . . It is no exaggeration to say that nothing could be achieved without their aid'. Women, the 'key-stone of all human societies', had achieved a new level of political consciousness and self-confidence, and recognised, 'that to fight for the Liberation of her country was to fight for her own Liberation ... The hub on which we will build the Algeria of tomorrow' ${ }^{29}$ As another document of 1957 proclaimed, 'A people among whom women live on the margins of national life is only a half of itself. It is atrophied. Much more serious still, it slides slowly and surely towards a certain death' ${ }^{30}$ However, the moudjahidate were invariably required to fulfil traditional gendered support roles as nurses and aids to male fighters, and they were never granted a position within the military gradation of ranks or placed in authority over men. For example the first woman doctor to reach the maquis was Nafissa Hamoud, but when the less experienced Mustapha Laliam arrived he was immediately promoted over her as chief doctor of Wilaya III. ${ }^{31}$

In contrast to the uncomfortable relationship between ALN soldiers and the urban évoluées, there is little, if any, evidence that the presence of peasant women (moussebilate) was found disturbing or problematic. These illiterate and anonymous women, who at great personal risk provided a global support function that was even more vital for the maquis than the moudjabidate, conformed quite 'naturally' to the everyday role that they had always fulfilled in peasant society, carrying wood and water on their backs, preparing food, washing and drying clothes and showing the customary forms of deference to men (reserve, avoidance of 
eye contact, not speaking unless spoken to, eating apart). ${ }^{32}$ The women from the city, educated and more vocal, presented a different challenge to men who were in many instances illiterate, shared a highly patriarchal mind-set, and, imbued with the teaching of religious leaders, viewed the distant city as a place of moral and sexual corruption.

The relationship of ALN fighting units to women in local society was in some instances violent and abusive. ALN units were constantly on the move within the rural-mountain zones, or deployed to carry out missions in distant locations, and the sometimes predatory attitude to women arose in part from the fact that soldiers, far from their home territory, were prepared to act like an army of occupation in their treatment of local populations. For example, Kabyles fighters often carried out raids against the MNA to the south of the Kabylia massive during which the Arab population, suspected of supporting the enemy, was treated with a brutality that was accentuated by regional, cultural and linguistic difference. One ALN report denounced its forces in the Nemenchas as 'a kind of tribal band rather than units of the national army', while elsewhere two cadres were denounced for calling the inhabitants of a village to a meeting where they insulted the women in front of the men, inciting one woman to protest, 'Colonialism comes and tortures us during the day. When you come we are pleased, but you also torture us'. ${ }^{33}$ Some maquisard seem to have operated like war lords exercising a droit de seigneur over women, ${ }^{34}$ but the oft-repeated stories found in the French media of commanders using young women as sexslaves, until their happy escape to the French side, need to be treated with caution. However, the ALN practiced a classic double-standard in punishing sexual misdemeanours, one order in Wilaya $\mathrm{V}$ indicating that those men found guilty of rape should not be beaten or executed, but be given 'a lesson in morality'. ${ }^{35}$

\section{Women and political organisation}

Despite the highly subordinate position of women within the FLN, there is some evidence of their beginning to move towards a more structured women's organisation, although their political and social activity was largely restricted to propaganda and educational work aimed at other women. The pro-communist UFA and the Messalist AFMA (chapter 1) had been dissolved in the early stages of the war, and the president of the AFMA, Mamia Chentouf, was expelled from Algeria. ${ }^{36}$ There is little evidence of the AFMA 'going underground' and providing a degree of continuity with the generation of militants (moudjahidate) that became prominent within the FLN during 1956-57.37 Djamila Bouhired, 
Hassiba Ben Bouali and Zohra Drif organised meetings of women during the general strike of January 1957 on the terraces of the Algiers Casbah to persuade them of the need to continue the struggle. ${ }^{38}$ This group was moving towards the idea of a more elaborate clandestine women's network when they were arrested. When Zohra Drif was finally tracked down by the parachutists in the Casbah, they were able to capture documents relating to this new structure, and Colonel Godard, through close interrogation, was able to build up a detailed picture of the proposed organisation which was to consist of 356 militants arranged in a classic network of clandestine cells.

According to Drif a number of cells were to be grouped together, each unit specialising in particular tasks: one group to counter the SAS by undertaking various forms of welfare work (aid to poor families and the sick); another to carry out propaganda and detect informers; one to locate and register individuals or families related to killed, tortured or disappeared militants and to provide assistance; others to act as messengers for the FLN network. The groups were to meet regularly once a week in each quarter for political discussion, or to listen to and debate FLN radio broadcasts from Morocco and Tunisia. The first direct action planned was to be a silent demonstration by women on a Friday at the traditional places of female association, the central mosque and the cemetery, as well as outside the General Government building, to protest against 'the death sentence passed on the two DJAMILA' (Bouhired, Bouazza), and also the imprisonment, execution or disappearance of husbands, brothers and sons. ${ }^{39}$ Drif's plan showed clear continuity with the forms of action undertaken by the UFA and AFMA between 1945 and 1954 which centred on social welfare support and demonstrations against the arrest and imprisonment of male nationalists (chapter 1). In the later stages of the war the perimeter of prisons in both Algeria and France continued to provide a focus where the relatives of prisoners could meet in solidarity to protest, sometimes synchronised with hunger strikes by inmates. ${ }^{40}$ Djamila Briki recounted how demonstrations developed outside the Algiers prison of Berrouaghia, and on one occasion a refusal to allow visitors triggered off a riot: 'From the barracks next door to the prison the soldiers unleashed their dogs on us and tried to disperse us. Our veils were torn by the dogs, but we did not budge. We threw stones at the prison gates'. ${ }^{41}$ The enormously strong emotional bonds between mother and son in Algerian culture, ${ }^{42}$ provided a powerful resonance to FLN propaganda and martyrology that depicted the heroic mother as a person who was transported by a superhuman courage in confronting, in the search for a lost son, the brutal parachutists and torturers of the French army. However, it is noticeable that even 
the most militant of women continued to see their own role primarily in terms of their nurturing and maternal function, a duty to support heroic sons and husbands.

In the rural areas the educated militants played a rather different function as political propagandists (morchida) who, when free from nursing fidayines, went into the surrounding villages to make contact with local peasant women and to raise their political consciousness. An ALN circular from May 1957 reflected a new stage in the planned organisation of 'women combatants'. The women, who were first to receive medical training at Wilaya level before serving in field hospitals or infirmaries, were also to assist local civilian women: 'the female combatant plays a social and political role in relation to her sisters', acting under the guidance of political commissars. In the first task, which had an unmistakable similarity to the ASSRA, she was 'a veritable social assistant working in the service of the Algerian woman. She must give useful advice to the latter, assisting her to manage the household, to raise the children, and to respect the rules of hygiene'. In the second, political role the task was to educate women on the current situation, explain the nature of the ALN and FLN and the aims of the 'Algerian Revolution', be prepared to answer all questions and act as a role model..$^{43}$ French intelligence officers in the Nord Constantinois, in an analysis of this captured document, noted that a drive was already underway to recruit women in Wilaya II where Messaoud Bouali had plans to incorporate fifty women into Mintaqa I. These women were not merely nurses, but 'veritable political agents' and, 'we are seeing, in this domain, a development that it is advisable to watch very closely'. ${ }^{44}$ The FLN was concerned at the appearance of the ASSRA that were first tested during the experimental Operation Pilot from 26 January 1957 onwards, and the ALN creation of similar female cadres two months later may well have been a response to this challenge.

Oral evidence by participants in the new organisation is plentiful: Khadra Belami, for example, an eighteen-year-old médersa student who joined the maquis of Wilaya II in January 1957, recounts:

We held numerous discussions with the population. We explained to the women what the revolution was since they had no links with the town and knew nothing about it. We explained to them that the revolution was being made to liberate the country, so that we could live free and so children could go to school. In addition we gave them educational lessons and in the health-care of their children. For example, they did not wash their infants until they were two years old, for fear that they would die. ${ }^{45}$

Malika Zerrouki, who was only fifteen when she joined the maquis in April 1956 to escape arrest, was taught nursing skills by Dr Si Ali: 'I 
would go out one or two hours walking distance to care for the women and children and to give vaccinations when we had received some. I tried to teach them the elementary ideas of hygiene, I spoke to them about the emancipation of women, about the Algeria of tomorrow' ${ }^{46}$ The young assistants from the city were shocked by the heavy burden of work of the peasant women, not only in raising numerous children but also labouring in the fields or tending livestock, while waiting handand-mouth on their husbands. In some instances they were prepared to challenge traditional gender roles. Yamina Cherrad recounted: 'When I tried to give the men some advice about this, they told me to look after my own affairs. But the women adored us ${ }^{, 47}$ Fatiha Hermouche gained the trust of women in one hamlet, even learning Kabyle, and discussed the problems which they faced as women. The inhabitants agreed to swap roles for one week, the men undertaking the heavy tasks of carrying water and wood, while the women took care of the house, but after only three days, 'the women missed going down to the spring and the discussions and, finally, everyone resumed their usual occupation' ${ }^{48}$

Finally, a quite exceptional use was made by the head of Wilaya V, Abdelhafid Boussouf, of a small group of highly trained women agents who were sent in eight mixed teams consisting of one man and one woman, to carry out clandestine investigations of the ALN organisation in each zone. Six of the eight agents (contrôleuses) were lycée students and activists in the Oudja section of the Union générale des étudiants musulmans algériens (UGEMA) and two were lycée students from Tlemcen. ${ }^{49}$ After an individual interview by Boussouf, who was to gain a sinister reputation as the organiser of a powerful police and intelligence apparatus, ${ }^{50}$ the recruits received a two-month training in the history and organisation of the FLN, guerrilla tactics, report writing, the use of small arms and other agent skills. Malik Hadjaj was given the task of reporting on MNA activity in Tlemcen, but the general mission of the teams was to report on the structure of the FLN organisation, the morale and combative state of militants, relations with the people and their morale, the state of welfare provision, and receptivity to French propaganda. ${ }^{51}$

The women controllers were also given the special task of investigating 'the feminine world in general', and to engage in political work among the local women. Rachida Miri noted:

Above all we had to motivate the women. We listened to what they had to say and, among other things, gave them lessons in hygiene. In fact to some extent we carried out the same work as the French. It was necessary to thwart the French agenda and especially of the SAS. During our training 
programme Boussouf repeated that the FLN was entrenched in the people, 'like fish in water: if the water was drained, the fish die'. ${ }^{52}$

The agents under Boussouf's direction carried out social and propaganda work that was in many respects like that of the morchidate in other Wilaya, but in their training and mission there is a sense of the way in which women controllers were being deployed as part of a highly efficient and centralised apparatus to police the ALN internally, rather than to forward a progressive emancipation agenda.

\section{Marriage and the FLN couple}

As has been seen in the previous chapter, the personal status law provided the fundamental touchstone in relation to women's rights and social position, the core site in the contest over modernity, national identity, cultural resistance and patriarchy. This section explores the extent to which the FLN, particularly in the internal maquis, made any impact during the course of the war on the deeply embedded sociocultural, economic and political practices relating to gender, the relative functions and power of men and women, and the overall emancipation of women. FLN regulation of marriage, divorce and relations between couples provides the best evidence of how it translated policy into concrete practice.

Despite the fierce puritanical and authoritarian opposition by many commanders to relationships between soldiers and women in the maquis, in some regions, most notably Wilaya II and IV, more secular and liberal leaders created a climate that was sympathetic and open to the presence of women and, almost inevitably, strong attachments grew between them and the soldiers. The unusual conditions of the maquis, in which young men and women were removed from the influence of the family, which usually controlled liaison, meant that companionate relationships could develop based on mutual love. ${ }^{53}$ Local commanders, who acted virtually as guardians, were constantly having to decide how to respond to requests from rank-and-file soldiers (djounoud) for permission to marry. A very detailed 1959 directive on marriage in Wilaya IV shows how some of these issues were regulated: the soldier should ideally marry a woman from a family of 'moudjahidines and Martyrs', must have at least one year of service in the maquis, be of exemplary morals, and make his request via the military hierarchy. ${ }^{54}$ There are some indications in the order of a liberalisation of marriage arrangements, perhaps in response to the French reforms of 1959. While the 'act of marriage will be, taking account of the conditions of war, 
in conformity with the principles of Islam', the traditional bride-price should be kept to a minimum and symbolic sum. The minimum age of marriage for women was set at sixteen years, one more than under the French law, and the maximum age gap between spouses was set at fifteen years. While it was acknowledged that the woman's decision to marry was still under the control of the parents or guardian, who would be consulted where possible, it was also necessary for women to give their free consent. Although the couple was allowed, where possible, a honeymoon of one week, after that the wife was not allowed to accompany her husband in the maquis. ${ }^{55}$ Each zone was allowed to grant permission for a maximum of ten marriages per month, but this might be reviewed or stopped in the future if the arrangement caused problems.

How did such orders work out in practice? Yamina Cherrad faced no opposition: 'I was married in November 1960 with Doctor Benaceur. Permission was given to us quite readily', ${ }^{56}$ although she went on to indicate the difficulty of sustaining a marriage relationship under the conditions of guerrilla warfare. A month after the marriage her husband was posted elsewhere and was killed in 1961. Yamina was pregnant and for the birth she was sent from the maquis to stay with people in Djijel, 'I did not know them, they welcomed me into their home, I gave birth and rejoined the maquis with the infant two months later. I worked in the infirmary as before. I was well regarded'. Up until late 1957, when the ALN was able to maintain control over large areas of the interior and to establish relatively secure bases, commanders seem to have been more prepared to accept the presence of married couples. After this, as the Challe offensive made for permanent insecurity and the moudjabidate were ordered to retreat across the border into Morocco or Tunisia, regulation appears to have become more draconian, as in an order of July 1960 in Wilaya III, 'the maquisard who gets married without authorisation from the ALN and without the knowledge of the people will be executed. If the marriage was not authorised but was concluded according to Muslim law, the person concerned will be condemned to one month prison and then moved elsewhere. Non-commissioned officers and officers will face the same penalties'. ${ }^{57}$

The conditions for relationships to develop between couples within the ALN maquis were exceptional compared to those found in peacetime society. The controlling hand of family males was absent and the ALN commanders acted in loco parentis to assume the role of guardian in deciding who could marry and to ensure that the normal interests of patriarchal regulation were respected. The FLN, in its attempt to create a counter-state, also established its own juridical and bureaucratic system to regulate marriage, family law and a civil register for the entire 
Algerian population. The Soummam Congress of August 1956, the first opportunity since the start of the war for the FLN to create a coherent organisational structure, showed a clear intent to regulate family life through welfare provision, especially monthly allowances for the families of ALN soldiers, or the dead and imprisoned, as well as by a system of local courts. ${ }^{58}$ The judicial system in the rural areas operated at two levels, that of elected Assemblées du people in the villages or committee of five (referred to by the French as the OPA) which settled minor issues, and through peripatetic military tribunals for more serious offences.

As the ALN gradually expanded and established its control over new areas of the bled it frequently asserted its authority over the local population by integrating existing political leaders, such as the council of village elders (djemâa) or tribal heads. ${ }^{59}$ This tactic extended to the integration of traditional religious leaders (imams, talebs, cadis, educated Ulemas) into the OPA structure precisely to oversee and direct areas of local life to do with family law, justice, religious practice and education. A report from the SAU of Clos-Salembier in April 1960 found that the Ulema, although constituting only 2 per cent of the OPA, were to be found at all levels of the organisation administering justice: 'In relation to religion they are opposed to any evolution. The fines imposed by the Ulemas on those who infringe Koranic regulations are always very heavy' ${ }^{60}$ This conservative application of customary Islamic law is confirmed by other FLN orders, like one sent out in Wilaya III in late 1956 or 1957: 'The heads of the religious foundations (biens habous) will watch over the rigorous application of the laws and regulations contained in Muslim jurisprudence when they have to resolve affairs relating to marriage, repudiation, etc.' ${ }^{61}$ This suggests that the FLN, instead of sweeping away the older generation of religious leaders in order to install a new revolutionary order of progressive and more secular justice, integrated them and in doing so maintained at the grassroot level a seamless continuity with pre-war custom and practice.

This conservative ethos was also evident at the higher levels of the FLN judicial system. The minutes of a meeting (majlis) of justices (cadi) in Wilaya I in October 1960 reaffirmed the practice of the dowry, widely condemned by modernisers, setting this at 6,000 to 30,000 francs. In went on to support early marriage at puberty as an Islamic check on illicit sex: 'Marriage of young girls without a spouse (virgins and older girls). To put a stop to the debauchery that is tending to become generalised, the majlis has decided that every effort and honest means should be employed to marry young girls who are still without a husband, especially those who fear marriage or who give themselves over to debauchery'. It was agreed not to accept any accusation of rape brought 
by a women unless this could, according to the Koran, be confirmed by four witnesses, in the absence of which the accuser would receive eighty lashes of the whip. ${ }^{62}$ The fierce puritanical justice of the FLN was reflected in the harsh treatment of moral, and in particular, sexual delinquents. One ALN directive ordered to 'kill all women and men who lead an evil life', ${ }^{63}$ and adultery was on occasions punished by execution, including the case of one man who, 'slept with the wives of soldiers and civilians. He would wink at every woman he passed by. And he was a major informer. He was executed by judgement of the ALN' ${ }^{64}$

The FLN decision to surrender religious affairs and justice during the war to the clerics was to have long-term consequences for women's rights, and set the scene for the conservative policy adopted after independence (chapter 11). However, as Gilbert Meynier has shown, FLN policy and practice at the Wilaya or local level was far from monolithic and a more modern idea of marriage can be found in some areas. Yamina Cherrad remarks how the female propagandists in the ALN spread a more enlightened model of marriage: 'The dowry was limited and it was forbidden to force a girl to marry somebody who was much older than her'. ${ }^{65}$ Perhaps nowhere was the potential shift towards a modern concept of the couple more marked than in France. Algerian labour immigrants had been arriving in France since the first decade of the twentieth century and, through their close contact with the French proletariat and urban life, had some experience of European life-styles and culture. In Paris by the 1930s some 10 per cent of all immigrants were married to, or cohabiting with, European women. ${ }^{66}$ During the War of Independence the number of Algerian women in France increased dramatically as they fled the violence and resettlement of the French army, and this meant that young immigrant men and women could escape the conservative restraints of family and society in Algeria. However, the FLN Fédération de France sought to impose its political and moral authority over the immigrant community, to create a disciplined and autonomous 'counter-state' that would segregate Algerians from attempts by the French police and authorities to control them and to gain intelligence. ${ }^{67}$ This included a system of Comités or Commissions de Justice that regulated all matters of disputes between Algerians, and supervised marriage and divorce. Internal FLN documents, for example, record the celebration of marriages, the payment of fines for unauthorised marriages, and attempts by the Paris Commissions de Justice to reconcile couples before they had recourse to divorce: 'Rue Polenceau: Dissension between spouses. Settlement not being possible, divorce was pronounced', and 'Rue des Partants: Divorce pronounced between spouses: a 5,000 Fr. fine'. The Lyons Comité de Justice in March 1960 
even recorded a 1,000 Fr. fine on a polygamous Algerian who had failed the Koranic duty to treat wives equitably, and intervened in the case of a man, 'whose wife has left him and we gave her a warning and made her return to the conjugal home'. ${ }^{68}$

FLN emigrants struggled, in the absence of religious authorities and their guidance, to regulate themselves and apply a legitimate interpretation of Islamic law by reference to the Koran. In the autumn of 1959 the anti-terrorist police seized in outer Paris (Seine-et-Oise) a copy of a detailed FLN instruction to the Comités de Justice on how to adjudicate on matters of marriage and divorce, the Règlement concernant les marriages et le divorce suivant le droit musulman. ${ }^{69}$ These liberal regulations appear to have been influenced by the debate surrounding the new marriage and family code passed by the colonial government on 17 September 1959 (see chapter 8). In particular the Règlement insisted on the ideal of companionate marriage, the happiness of the domestic circle depending on, 'the good will of the two spouses and their good relations'. Both women and men, it stated, must give their free consent to the alliance: 'Above all marriage must be a union based on affection, and agreed together and with complete accord between the two fiancée and with their reciprocal consent'. The Règlement, as in the case of the Ordinance of 4 February 1959 which required the couple to attend in person before the officer of the état civil, required bride and groom to appear before the president of the Comités de Justice who would interview both to ensure that neither had, 'undergone any pressure or threats on the part of their parents or guardians ... All unions carried out against the will of the young man or the young girl is strictly forbidden'. The dowry should be quite nominal, not more than 5,000 Fr., and gifts limited. Husbands who used blows or violence towards their partners would be severely punished by the Committee. Husbands should not resort to repudiation or divorce without careful consideration and should refrain from appropriating the dowry that was the legal entitlement of the wife.

Although the Règlement contained some quite conservative or conventional formulations, for example that the spouse must 'keep the honour of her husband intact', there are clear indications of a grassroots evolution of emigrant society towards a new model of marriage and the family. ${ }^{70}$ But at the same time this process was being neutralised by a growing debate within the FLN, inspired by religious conservatives, who attacked the widespread existence of mixed marriages with European women as a threat to the integrity of Algerian culture and identity. ${ }^{71}$ The debate on mixed marriage, which began to assume a racist and defensive tone, was to fuel a highly negative current of 
opinion within post-independence society that supported the status quo on Muslim women by extolling them as the pure guardians of Algerian identity. ${ }^{72}$ In the Règlement there are signs of this male agenda to guard the moral purity of the nations women and mothers: 'It is formally forbidden for our compatriots to live in debauchery with our Algerian sisters or to keep them as mistresses'. This puritanical ethic sat rather uncomfortably with the fact that the Fédération de France raised huge sums of money through the spéciaux, the taxing of petty criminals, pimps and prostitutes. One wife of a bar-owner was recruited by the FLN to organise and lead twenty women, all prostitutes, divided into four cells whose job it was to carry out the monthly collection in the redlight districts of Barbès, Pigalle, Clichy and the Champs-Élysées. The women also acquired guns and bullets from clients, notably American service-men from a base in Orleans. ${ }^{73}$

\section{Demobilisation of the moudjabidate from the maquis}

In late 1957 and early 1958 the ALN began to remove most of the moudjabidate from the maquis, a decision that was to mark a shift away from a more open or innovative policy towards women towards a reassertion of male authority. But, as will be seen in the following section, this left the FLN in a weakened position to counter the EMSI and women's circles at the very moment they were being rapidly expanded after May 1958. From October 1957 onwards the Wilaya commanders took the decision to remove, apart from some exceptional individual cases like Mimi Ben Mohamed, ${ }^{74}$ all the nurses and to integrate them back into civilian life in the towns or across the frontier in Tunisia and Morocco. Courrière reports that in Wilaya III this decision was made by Colonel Amirouche at a meeting on 22 October 1957, in an attempt to prevent the tensions created by the fact that some soldiers were allowed to marry nurses, while the rank-and-file had to suffer sexual abstinence or faced execution for sleeping with peasant women. ${ }^{75}$ While this was certainly a problem, for example Omar Oussedik was criticised for keeping his wife, Nassera, in the maquis, ${ }^{76}$ the primary reason for this change in policy was a significant shift in the nature of the war.

Until 1957 the ALN was able to create quite stable bases or safe zones, including infirmaries, in the mountain villages, so that the moudjabidate had a reasonably comfortable, if austere life which they shared with local peasant women. This phase appears to have been one in which it was easier to segregate the nurses, especially in their sleeping arrangements, from the ALN soldiers. However, after Operation Pilot the French army began to pursue a much more aggressive policy of using 
commando units to harass the ALN in its redoubts and this forced the ALN to abandon static positions close to villages for a constant movement between concealed caves and hide-outs. ${ }^{77}$ The constant forced marches, often over long distances at night, were physically exhausting for the fittest of men, and it became clear to the FLN command that few women could cope with the desperate conditions faced by ALN units. Although no central FLN order has been found, it seems likely that such a decision to withdraw women was made since several Wilaya moved in the same direction: Wilaya $\mathrm{V}$ at a meeting of 2-7 October, ${ }^{78}$ Wilaya III on 22 October, and Wilaya IV in 'late 1957'. Azzedine notes in his memoirs that the nurses were withdrawn by Wilaya IV because of the exhausting physical conditions and growing danger that units faced, ${ }^{79}$ and Kheira Bousafi agrees, 'Towards the end of 1957 the brothers called us to a meeting and told us that there had been too many skirmishes, that things were too tough, and that we were going to depart for Tunisia. We cried saying that we wanted to stay with them. But they refused' ${ }^{80}$ By early 1958 most women had been withdrawn, apart from a few, mainly in Wilaya II, IV and V, who showed exceptional resilience and fulfilled particularly valuable work. ${ }^{81}$ Baya Laribi was one of the very few who could have stayed, but she admits the conditions were too tough, 'I was too tired, I couldn't carry on'. 82

However, as ALN units retreated into the mountains away from their provisioning base in the villages, there appeared a rather contradictory practice of recruiting young and extremely tough mountain women (amilate) to move constantly with the soldiers to cook bread and wash clothes. ${ }^{83}$ Perhaps peasant women were regarded as physically tough unlike the effete women from the towns, but as has been seen, the rural women presented little challenge to customary gender relations, and conservative commanders were eager to seize on any opportunity to marginalise the troublesome évoluées. Wilaya II issued an order in December 1958 that any women joining the ranks would be sent back, even if they risked arrest by the enemy, and any males accompanying them were to be executed. ${ }^{84}$

That the door had been firmly shut on any open or progressive agenda was made clear by the subsequent fate of the nurses and auxiliaries who were evacuated across the border to Tunisia and Morocco, and immediately disciplined to conform to traditional gender roles. Malika Zerrouki recounts how she crossed into Tunisia in a group of about fifteen women from Wilaya IV who were then abandoned in a villa: 'there was nothing for us to do, which was really annoying. We could not go out, no kind of life, and this went on for a long while, for some seven to eight months'. The young women, who had gained a strong 
sense of independence in the maquis, complained bitterly and were locked up in a cellar until rescued by Colonel Ouamrane..$^{85}$ That this was no accident can be confirmed by identical events in Morocco: when Michel Launay visited the refugee camps in Oudja in the summer of 1961 he found that the moudjabidate had been virtually claustrated in a kind of boarding house, 'The ALN considered itself to be like a father and conducted itself in their case like a head of a traditional family anxious about the reputation of his daughters'. They found it difficult to readjust from the freedom of the maquis to reveiling. ${ }^{86}$ The feminist activist Hélène Vandevelde-Daillière was told by her child-minder Sabah how she had joined the ALN in 1957 aged fifteen, only to be evacuated to Oudja where she was one of 108 ex-maquisards, 'locked up like prisoners. We did not even have enough to eat and three of us started a hunger strike to protest. Colonel [Boumédienne] came to see what was going on, and it was me who explained all our demands. He slapped me in the face. That was his reply. I tried to commit suicide' ${ }^{87}$

Eventually the FLN began to organise structured training programmes for women in both Tunisia and Morocco in nursing, secretarial skills, weapons assembly and radio transmission. ${ }^{88}$ In early 1961 the FLN was carrying out a census of all young Algerian women aged fourteen to eighteen years in Fez to progressively enrol them into paramilitary organisations, but this plan does not appear to have come to anything. In general terms Algerian moudjabidate found themselves restricted and confined by the powerful hierarchical and severely disciplinary bureaucratic apparatus of the external army (EMG). Even the most well educated and experienced of women were excluded from assuming any significant political role in the FLN. Boumédienne's suggestion that a woman should be appointed to the top executive Conseil national de la Révolution algérienne (CNRA) was rejected, ${ }^{89}$ and the most prominent women, like Mamia Chentouf, former militant of the AFMA (chapter 1), and Djamila Rahal, were largely restricted to symbolic acts of international solidarity that served the purposes of FLN propaganda such as attending various international women's conferences in Vienna, Copenhagen, Cairo and elsewhere..$^{90}$

There are signs that Djamila Rahal in Rabat attempted to establish an organisation of Algerian women and sent a delegation to discuss the matter with Chawki Mostefaï, a senior FLN diplomat, but this seems to have had no outcome. ${ }^{91}$ As Gilbert Meynier notes, the wives of leading army or FLN personnel remained largely invisible in line with the Algerian social norms of excluding married women from the public sphere and preserve of males, ${ }^{92}$ an invisibly that contrasted with the political role of the wives of French army officers. From 1958 until the 
end of the war the small elite of educated Algerian women was significantly marginalised by the FLN, re-absorbed from the 'heroic' and more experimental phase of moudjahidate engagement of 1956-57, which most of the male hierarchy came to regard as a threatening subversion of traditional gender roles, and once again safely constrained within a subordinate position.

\section{FLN reactions to French emancipation}

During the year from May 1958 to May 1959 the FLN found itself suddenly and dramatically confronted with an aggressive and multifaceted French campaign for emancipation, a propaganda offensive that included an expansion of the EMSI, the orchestrated unveiling events of '13 May', the creation of the MSF circles, the extension of the vote to women in September, and the promulgation of the Ordinance on personal status on 4 February 1959. The French strategy was designed by the Fifth Bureau to maximise disarray in the FLN by seizing on a latent contradiction between the growing prominence and liberty of women militants in urban and rural networks and the weight of conservative and patriarchal values. ${ }^{93}$ The journalist Hansjoerg Kock was fully aware of the dangers created for the FLN by the French reforms: for the, " "évoluées women" ... soldiers, nurses, informers, they take part in the military struggle hoping that the national Revolution will also grant them a social Revolution and the benefits of personal liberation. But, in the heart of the FLN certain strictly conservative forces are opposed to any kind of emancipation of women'. But, he added, 'it is going to be difficult for the Algerian rebels to oppose this reform [of personal status]', since women in the towns have long called for such an emancipation, while young women no longer wore the veil in which they saw 'the detested symbol of a tyranny which is not based on the Koran' ${ }^{94}$

The ALN inside Algeria was quick to recognise the very real propaganda dangers presented to its own position among both the rural and urban inhabitants by the French emancipation campaign that could offer not only rhetoric, but very real material rewards such as medicines, food supplies and clothing to a desperately poor population. FLN anxieties were revealed in detail in an internal directive, Propagande et contre-propagande à mener vis-à-vis de la femme musulmane, which was found by the French army on the body of an assistant political officer, Si Boumédienne, killed in the south Oranais on 26 November $1958 . .^{95}$ The circular noted that, 'the enemy is proposing to free our Algerian sisters from archaic traditions that keep her under their yoke. They show a keen interest in her evolution and do not hesitate to use all means to 
hasten her "emancipation" copied on that of the Frenchwoman'. The directive, which instructed ALN cadres how to engage in a planned counter-propaganda campaign, noted that the enemy had two goals: by winning the trust of Algerian women it could get at husbands, brothers and sons, 'the instigators of the Algerian revolution', and secondly achieve important propaganda goals by informing the world of its so-called 'humanitarian task'.

The ALN analysis went on to recognise the sophisticated nature of the French emancipation offensive, how propaganda was tuned to the varying conditions of Algerian women in urban or rural societies. By deploying Muslim women as social assistants who had a close knowledge of local languages or dialects and way of life the army had a better chance of psychological actions that would pierce the vulnerable spots, 'which had the best chance of being effective and gradually succeeding; it exploits maternal and paternal love, the pride of the happy mother that one takes interest in her son'. There was a real possibility that the emancipation agenda would win over women, since they were by their nature susceptible to praise and self-promotion: 'In seeing certain powers granted to her that she did not have before, women, sensitive to this attention, to this interest that is shown in them, will be appreciative and try to impose their opinions inside the household, and will be invited, should this happen, to leave the maquis, to move to regroupement camps, to provide intelligence'. The directive provides evidence of the way in which a central theme of nationalist discourse, the idea that the private domestic world of women represented the ultimate bastion of Algerian identity and security, was diffused into the lower levels of the ALN maquis.

The directive then concluded by outlining various forms of counterpropaganda which, in a mirror image of the French campaign, should be carefully adapted to regional or local variations in the condition of women, especially differentiating the more religious societies of the bled from the secular urban context. In approaching 'our Bedouin sister', the highly religious and nomadic peoples of the Sahara, the aim should be to remind women of the atrocities, massacres and humiliations imposed by the French, and on the dangers presented to Muslim faith and identity. By agreeing to vote, 'you, Algerian women, you agree to become French, thus to renounce your RELIGION, your COUNTRY . . . you commit yourself to make ALGERIA a French land'. The directive played on the profound populist fear of secularisation, and on one of the great anxieties of rural women that emigration would lead sons and husbands to become 'corrupted' in France, to enter common-law relations with European women, and to break ties with the kin solidarities of 
home. Equally threatening was the army's educational programme for children through which, 'The enemy teaches them its language so as to de-Islamise them ... When grown up they will repudiate their parents, marry French women, and will become soldiers to fight for France'.

However, for 'our urban sisters', the better educated and modern women of the towns, the message should be somewhat different and lay less emphasis on the protection of religion and custom, than on the fact that a progressive emancipatory agenda did not have to come from France but was perfectly compatible with the Muslim state once liberated from colonial domination: 'They lure us with the idea of the emancipation of other Muslim sisters in independent countries, like Egypt, Syria, Turkey .... One does not have to be French to become emancipated'. Finally, it was recommended that the ALN should counter the EMSI and MSF by increasing the vitality of the OPA: political commissars needed to increase their tours of villages to speak to the people, while the material and seductive aid of the French should be countered by parallel operations, the distribution of clothing and money to the needy, and increased activity of ALN nurses.

The Fifth Bureau, in its analysis of this captured document, were ecstatic at this proof of the success of their emancipation strategy and increased its determination to widen the activity of the EMSI. ${ }^{96}$ The Bureau in March 1959 circulated extracts from the directive to encourage all the EMSI teams through this evidence of their success. ${ }^{97}$ Some of this optimism was warranted since by late 1958 the FLN faced very real difficulty in implementing its own counter-propaganda strategy. The huge, 'steam-roller' offensive of the Challe Plan, combined with the impact of the high-voltage defences along the Tunisian and Moroccan borders in cutting off supplies of manpower and military equipment to the ALN in the interior, meant that the maquis was desperately short of weapons and supplies and was reduced to desperate and continuous long-distance forced marches to survive. This made political and welfare work with local village populations ever more difficult. To make matters worse the ALN decided to demobilise the moudjahidate to Morocco and Tunisia, so removing the educated militants who were engaged in political propaganda and welfare work, at the very moment that EMSI and MSF groups were rapidly expanding their activities. Faced with this crisis the FLN appears to have instructed its ex-moudjabidate to try and infiltrate the EMSI so as to subvert the French operations from within and to provide intelligence (see chapter 7). But the most direct response of the ALN on the ground to the French emancipation strategy was to engage in compliance terrorism that warned Algerian women to abstain from voting or to boycott EMSI activities, while ASSRA and other social 
workers were targeted for assassination. However, the ALN in general refrained from using physical violence against ordinary Algerian women for making use of SAS or EMSI welfare: it was too aware of the desperate conditions facing peasant women and their children to try and deny them access to army supplies of medical aid, medicines, food and clothing, and in addition this provided a source of materials that was filtered through to the local maquis.

Finally we need to consider how the FLN decided to respond centrally to the French emancipation agenda through its own public declarations of policy. The most obvious counter, one that was best represented by the work of Frantz Fanon, was to reveal the way in which the French programme was primarily driven by counter-insurgency objectives. However, there was a real danger that a global and all-embracing assault on the French agenda, in denouncing reformism as part of an insidious colonial plot, could end up denigrating the very principle of progressive emancipation and women's rights as alien and anti-national. The remaining part of this chapter examines two key strands in FLN discourse that were used to camouflage its conservative position but which were to carry negative, long-term implications for the post-independence women's movement: firstly, the argument that a programme of women's rights should be put on hold until independence had been achieved, and secondly, the construction of the myth of women as the bastion of Algerian social and religio-cultural identity.

A recurrent feature of wars of national liberation during the twentieth century was the idea that women, who frequently made a huge sacrifice in the struggle, would be compensated with some form of political 'reward' when victory was finally achieved in the form of progressive legislation or socio-political emancipation. ${ }^{98}$ The emergency suspension, however, of a clear policy on women appeared to be justified during revolutionary or resistance wars when indigenous forces needed to prioritise the armed struggle in order merely to survive and when the maquis was lacking in any semblance of a state apparatus. FLN propaganda during the war embodied this discursive strategy: liberation from the yoke of colonialism and capitalism would, of itself, create automatically the conditions for female emancipation by restoring the integrity of a non-colonial religio-utopian order. This position carried some obvious dangers in that it proved a useful instrument or cover for not having to develop any specific programme, even during the later stages of the war when a fully operational FLN bureaucratic apparatus existed to engage in planning for a post-independence society. However, despite the general refusal to elaborate a blue-print of the position of women in the future socio-political order, FLN documents frequently 
revealed the mind-set of the leadership, as in a Notes aux militants $d u$ FLN circulated in early 1957 :

Algerian women living for decades under Medieval material, moral and intellectual conditions constitutes a half of the body of the nation that is almost unconscious.

In consequence, particularly urgent help must be lavished on them, in conformity with the spirit of our National Revolution and the new and numerous demands we face, to prepare them for the tasks of liberation and the construction of the future Algeria within the framework of their natural privileges as wives, mothers, housewives and citizens. ${ }^{99}$

The idea that women in post-independence Algeria would essentially stay confined within their maternal and domestic functions was occasionally affirmed quite bluntly, as by Captain Si Allal in Wilaya V: 'I remind you for the last time that it is forbidden to recruit in the zone, without authorisation, female soldiers and nurses. In an independent Algeria the freedom of the Muslim woman will stop at her threshold. Women will never be the equal of men'. ${ }^{100}$

The claim that the FLN was in no position to develop a cogent policy on women during the course of the war because of the priority and immediacy of armed struggle was flawed since from 1956 onwards it was laying the basis for a state apparatus that by 1958 assumed the form of a Provisional government (GPRA) with a fully-fledged administrative structure. By far the most important foundation was laid at the Soummam Conference held secretly in the interior in August 1956, and this was to provide the only major statement on women until the 'left' Charter of Tripoli on the eve of independence (28 May-7 June 1962).

In the Soummam platform the section Le movement des femmes was relegated to the sixth and last place under the heading 'Methods of action and propaganda' after the movement of peasants, workers, youth, intellectuals and liberal professions, and small businessmen and artisans, as if women occupied a separate enclave. ${ }^{101}$ Women received the usual accolade as heroic fighters, but their brave sacrifice for the national cause was framed mainly as a form of moral support or succour for the male warrior, 'the moral support for combatants and resistance fighters'. ${ }^{102}$ The shining example of female heroism held up, in a display of what Meynier has called an 'everyday Masculine narcissism', ${ }^{103}$ was 'the recent example of the young Kabyle girl who rejected an offer of marriage because it did not come from a maquisard'. Overall the Soummam platform represented a step backwards on the position that women had come to occupy in the ALN and it was symptomatic that Ramdane Abbane, the leading ideologue of the FLN, on arriving 
at Soummam was astonished at the presence of young women who he felt to be 'out of place' in the maquis. ${ }^{104}$ As Amrane notes of both Soummam and Tripoli, 'The political texts are clear, the militant woman is courageous and admirable, but she must stay confined within the tasks that are in harmony with her female nature'. ${ }^{105}$

The failure of the FLN to go much beyond grandiloquent, but ultimately vacuous, statements on women's heroic role was reflected in the difficulty that rank-and-file militants had in imagining or conceptualising the post-independence order. Mimi Ben Mohamed, a well-educated militant who achieved the highest position of any nurse in the maquis, recounts the conversations she had with her colleagues about their dreams for the future:

They each had their little ideas about the future ... Right, there is the problem of women. In the case of women how was it going to be ... For example, the beaches ... some saw private beaches for women ... On the independent women they were generally not in agreement. Some were against the veil, others were for it ... We didn't know at all how independence was going to be since we couldn't form a picture. ${ }^{106}$

The absence of a clear political project, the blurred vision restricted to questions of unveiling or a vague utopia based on the segregation of beach swimming, is indicative of the extent to which the FLN had failed to engage in a basic political education of the rank-and-file as to the future position of women. The failure to outline a programme also left the hands of the post-independence regime untied and free to pursue what turned out to be a deeply conservative policy.

\section{Women: the myth of the national bastion}

The second and potentially most negative, but insidious strand underlying the FLN failure to conceptualise a coherent policy for women arose from the topos or ideological construction of a 'fortress identity'. The roots of this topos, which were shared equally by Muslim and European intellectuals from at least the 1930s, if not earlier, derived from the recognition of two spheres in Algerian culture and society, the private domestic space of the home which belonged to women and children, and the public sphere of the adult male who represented the family in all external matters. This model derived in part from the classic bourgeois doctrine of separate spheres that became universalised in European culture between the Enlightenment, Rousseau's Emile providing a foundation text, and the 1950s. The model crucially essentialised the inherent, and therefore unchangeable, nature of women as nurturing, 
maternal and sentimental, as opposed to males who were geared to the external universe of physical force, conflict, politics and rational decision making.

From the 1930s onwards the Algerian intelligentsia, particularly the Ulema, re-interpreted the western model by idealising the private sphere of the family as a religious space in which women were the guardians of tradition, the transmitters of the essence of Muslim values and identity, through the education or socialisation of children and the future generation. As we have seen (chapter 1) the colonial rulers and the Muslim conservative elites entered into a tacit alliance by which the former would respect the sanctity and autonomy of the religious sphere, defined most crucially as the law of personal status (marriage, divorce), in exchange for the latter quietly accepting the status of subjects without full political rights who would not challenge the colonial order. As the nationalist movement gained strength from the 1930s it, like nationalism in many other 'Third World' struggles of decolonisation, increasingly represented women as the bearers of tradition. ${ }^{107}$

The myth of women as the fortress of religious, cultural and national identity has been widely treated by contemporary historians not as an ideological construct but as an objective, sociological phenomenon that has been used by them as the basis for the understanding of resistance to colonialism. Such interpretations are legion in the analysis of Algerian culture and society, but typical is the comment of Nefissa Zerdoumi that, 'the space of women shrunk to the dimensions of a refuge which was of primary importance to keeping and preserving. Thus women became the guardian of the Algerian-House instituted as a bastion of traditional values against foreign influences'. ${ }^{108}$ Frantz Fanon played a key role in the generalisation of this topos among Algerian and European intellectuals, the idea that French military occupation and colonialism since 1830 had profoundly destroyed the structures of Algerian society (tribal associations, landownership, customs) but had failed to penetrate and subvert the last bastion of Algerian identity, the sacred and private sphere of the family. The wisdom of the colonial administrator was phrased by Fanon as follows: " "If we wish to strike at Algerian society in its structure, in its capacity for resistance, we must first of all conquer the women; we must go and seek them out hidden behind the veil and in the houses where the men conceal them"... To convert women, to win them over to foreign values and to tear them away from their personal status, is to gain a real power over the men and, at the same time, to possess the practical and effective means to dismantle Algerian culture'. ${ }^{109}$ For Ferhat Abbas also, 'The Muslim woman loves children. As the guardian of moral values, she raises them in the 
ancestral traditions, the legends and myths. She constitutes the bedrock of the family cell, the dynamic element of tribal life ... And as she was particularly hostile to European penetration, she concentrated in herself the patriotism and unity of the people'. ${ }^{110}$

Rarely have historians or sociologists attempted to penetrate beyond the myth, to question or challenge this ideological construct. The colonial and nationalist idea of the 'family-as-fortress', rather than being subjected to critical examination, has survived in contemporary political science and sociology as a key interpretative tool with which to understand modern Algerian history. As such, what might be labelled 'Fanonist feminism' has served to reproduce a key element of this discourse: that the essential being of women in a liberated society is to fulfil her domesticated destiny as wife and mother, a destiny made sacred through its core function of guarding the holy nation. Few commentators have stopped to ask what it might mean for any progressive picture of contemporary Algeria if Muslim women should be idealised as the defenders of algérianité precisely to the extent that they were isolated from the mainstream of public and political life. It was not necessarily advantageous to the development of a modern society that a key model of basic socialisation and education of the future generation should ideally be placed in the hands of the most secluded, ignorant and un-educated section of society.

The popularity of the formulation of women as the fortress of identity was linked to the sentimental and patriotic theme of wives and mothers as heroic combatants, but at the same time it locked women into the status quo as guardians of the segregated and private sphere of the home, as reproducers and subordinate servants of males. By implication if women should try and encroach on the sphere of men, the public domain of politics, they would risk weakening the walls built around the domestic space which was a guarantee of the purity, integrity and continuity of tradition: emancipation could only be the work of the devil and subversive western design.

\section{Notes}

1 The most detailed FLN interpretation of the degradation of Algerian women as almost uniquely due to the impact of the exploitative colonial system is Saadia-et-Lakhdar, L'Aliénation colonialiste et la résistance de la famille algérienne (Lausanne: La Cité, 1961).

2 Amrane, Les Femmes algériennes, 247, notes the lack of any discussion or document relating to the initial recruitment of women, a process that occurred 'without any prior theoretical reflection'. 
3 Meynier, Histoire intérieure, 223-37.

4 On the different categories of FLN women combatants see above chapter 6, note 35 .

5 Amrane, Les Femmes algériennes, 221-5 on press reports during 1956-57.

6 Ibid., 91.

7 Horne, Savage War, 184-5; Reid, 'The World's of Frantz Fanon', 465-6, on Hassiba Ben Bouali and Zohra Drif's background as educated women from an upper-class background.

8 Georges Arnaud and Jacques Vergès, Pour Djamila Boubired (Paris: Minuit, 1957), 61; Ighilahriz, Algérienne, 45-55.

9 Although less well known, an identical situation existed for women militants in the Moroccan insurrection: see Baker, Voices of Resistance.

10 Yacef Saadi, La Bataille d'Alger, Vol. 2, 484, refers to Drif as his 'companion in arms'.

11 Amrane, Les Femmes algériennes, 112-13. On the Tillion-Saadi meeting see Donald Reid, 'Re-viewing The Battle of Algiers with Germaine Tillion', History Workshop Journal, 60 (Autumn 2005), 93-115.

12 Sylvie Thénault, Une Drôle de justice, 84-8. Jacques Vergès recounted this political and propaganda strategy of the courtroom in Le Salaud lumineux, conversations avec Jean-Louis Remillieux (Paris: Michel Lafon, 1990), 178-83.

13 Amrane, Les Femmes algériennes, 13, note 1. David Macey, Franz Fanon, 431, notes that a film on Djamila Bouhired, Héroine algérienne was shown at the Afro-Asiatic Solidarity Conference in Conakry, attended by Fanon and Sekou Touré in April 1960.

14 Simone de Beauvoir and Gisèle Halimi, Djamila Boupacha (Paris: Gallimard, 1962), which also includes de Beauvoir's influential article 'Pour Djamila Boupacha' published in Le Monde, 3 June 1960. See also de Beauvoir, Force of Circumstance (London: André Deutsch/Weidenfeld \& Nicolson, 1965), 500-5; Gisèle Halimi, Le Lait de l'oranger (Paris: Gallimard, 1988), 352-3; Lee Whitfield, 'The French Military Under Female Fire: The Public Opinion Campaign and Justice in the Case of Djamila Boupacha, 1960-62', Contemporary French Civilization, 20: 1 (1996), 76-90.

15 On the abundant literature on the Algiers heroines, see Borrmans, Statut personnel, 507, note 126 .

16 On the FLN propaganda use of photographs of armed women, see Amrane, Les Femmes algériennes, 243-4. Although there are 'official' ALN photographs of uniformed and armed all-women units, there is little evidence that they ever operated. However, many women in the maquis or underground accepted or liked to be photographed by their comrades posed with weapons. In many instances the women are smiling and playful, fully aware of the humorous element in transgressing an ultimate male preserve: see Gervereau and Stora (eds), Photographier la guerre d'Algérie, 166; AmraneMinne, Des femmes, 50-1, has a photograph of Kheira Bousafi, rifle in hand, on which she comments, 'I was not armed: in the photo it is a brother 
who has leant me his gun. The girls were not really armed, sometimes a little revolver: there were not enough weapons to go round'.

17 Meynier, Histoire intérieure, 226; Harbi and Meynier (eds), FLN: Documents, 604, 608: among the heroines was a woman 'T', who the day after the execution of her husband by the French, killed a soldier with an axe and seized his machine-gun.

18 Harbi and Meynier (eds), FLN: Documents, 612-13, tract of Wilaya IV, 'Appel de l'ALN aux femmes Algériennes'.

19 On these traditions see above Introduction, note 44 and 45; on Morocco see Baker, Voices of Resistance, 17-20, 167-8.

20 Najmabadi, Women with Mustaches, 221.

21 Launay, Paysans algériens, 376.

22 Amrane-Minne, Des femmes, 32, gives a figure of 2,000 women joining the maquis.

23 Harbi and Meynier (eds), FLN: Documents, 548.

24 Amrane-Minne, Des femmes, 78.

25 Meynier, Histoire intérieure, 226, minutes of committee for Wilaya I, 22 January 1957.

26 Ibid., 227-30.

27 Ibid., 230.

28 Amrane-Minne, Des femmes, 55, interview with Yamina Cherrad.

29 SHAT 1H2461/1, Renaissance algérienne, 2 [no date, 1957].

30 Harbi and Meynier (eds), FLN: Documents, 648. Wilaya V, 1957.

31 Amrame, Les Femmes algériennes, 254; Meynier, Histoire intérieure, 227.

32 SHAT 1H2461, the ALN journal Renaissance algérienne, 1, published by Wilaya III (seized by the army on 12 December 1957), in an unusual tribute to the peasant women as the unsung heroes of the Revolution, remarked on a change in the strict codes of gender segregation. The women on seeing the moudjabidines warmly acknowledged them: 'The most remarkable thing is the break with the old and rigorous custom that forbade women to speak to any stranger to the family circle. Now they do not hesitate to call to the Moudjabid, whether it be to offer him a drink or fruit'.

33 Harbi and Meynier (eds), FLN: Documents, 204, 245, note 23, 487-91.

34 Meynier, Histoire intérieure, 228.

35 Harbi and Meynier (eds), FLN: Documents, 448.

36 Ibid., 605.

37 Amrane, Les Femmes algériennes, 43, note 2, found that of the 10,949 registered after 1962 as FLN militants, only six were listed as having pre-war political affiliations (two PCA, four PPA-MTLD). This remarkably small number may point to a significant fissure between pre- and war generations of militants, and also a high level of political alienation between excommunist and Messalist militants and the post-Independence FLN regime. A report of the Ministry of the Interior, 15 December 1955, in CAOM 81F1218, notes that the MNA may have been organising women's cells. 
38 Amrane-Minne, Des femmes, 139, interview with Zohra Drif.

39 SHAT 1H2583, Organisation féminine de la ZAA, Second Bureau ÉtatMajor, 14 October 1957; see also Amrane-Minne, Des femmes, 140, for Zohra Drif's comments on the silent demonstrations.

40 On women's demonstrations outside prisons in France see House and MacMaster, Paris 1961, 112, 127-9, 233, 240.

41 Amrane-Minne, Des femmes, 213.

42 See Lacoste-Dujardin, Des mères contre les femmes.

43 SHAT 1H2582, FLN circular of Wilaya II, No. 9, 2 May 1957, found on the body of Said Harane, political officer of the Jemappes nahia, killed on 4 October 1957.

44 SHAT 1H2582, Note de Renseignements, 2e Bureau, 7 November 1957. This document is attached to, and provides an analysis of, the FLN circular of Wilaya II, No. 9, 2 May 1957.

45 Amrane-Minne, Des femmes, 34.

46 Ibid., 89-90; see also the interviews with Yamina Cherrad and Baya Outata, pp. 58,82 .

47 Ibid., 55.

48 Ibid., 65.

49 Amrane, Les Femmes algériennes, 87-9; Ryme Seferdjeli, 'Des femmes dans les missions de contrôle de la wilaya 5 pendant la guerre de libération', in Aâmal Al-Moultaka Adaouli hawla Nachaat wa tatawor jaïch Al-tabrir Al watani, 2-4 juillet 2005 (Algiers: Publication Ministère des Moudjahidine, 2005), based on interviews with four of the agents, Malika Hadjaj, Aouali Ouici, Rachida Miri and Yamina Chellali. The other four were Samira, Tarik, Khedidja Chellali and Aouicha Hadj Slimane, the last two killed in the maquis. SHAT 1H2582, captured FLN document from the head of Wilaya V to the Captain of Zone Three, 26 February 1957, with instructions on the mission of Yamina [Chellali] and 'Said'.

50 Meynier, Histoire intérieure, 336.

51 Amrane, Les Femmes algériennes, 87.

52 Seferdjeli, 'Des femmes'.

53 On the evidence of such close relationships, including love letters and photographs of couples, see Meynier, Histoire intérieure, 236-7; Harbi and Meynier (eds), FLN: Documents, 612.

54 SHAT 1H2582, Directive No. QA-20, Wilaya IV, seized 3 January 1959. CAOM 81F1222, a SDECE note, 18 August 1958, has an identical directive sent from Wilaya $\mathrm{V}$ command to the zones.

55 Harbi and Meynier (eds), FLN: Documents, 617, letter of Commander Si Mohammed, 17 May 1961, ordering Captain Si Tarik to remove his wife since this, 'appears to us to be damaging to your prestige, to your standing as a conscientious combatant, and to the example you give to all the moudjahidines'.

56 Amrane-Minne, Des femmes, 61.

57 SHAT 1H1619/1, quoted in Meynier, Histoire intérieure, 227-8. 
58 Minutes of the Congress of Soummam, 20 August 1956, in Courrière, $\mathrm{La}$ Guerre d'Algérie, Vol. 2, Appendix, 653-85.

59 Harbi and Meynier (eds), FLN: Documents, 619, Instructions on justice, Mintaqa LVIII (South West Oranie), 1956 or 1957 note, 'one must habituate the Tribal Council to render justice, if possible, in the presence of the political emissaries'.

60 CAOM 2SAS60, SAU note, 5 April 1960.

61 Harbi and Meynier (eds), FLN: Documents, 586, directive Wilaya III.

62 Ibid., 628-30, minutes of majlis, Wilaya I, 10 October 1960.

63 SHAT 1H2582, directive captured 17 April 1957 near Port-Gueydon.

64 Harbi and Meynier (eds), FLN: Documents, 628, 631.

65 Amrane-Minne, Des femmes, 60.

66 MacMaster, 'Sexual and Racial Boundaries', 95.

67 On the FLN Fédération de France as a 'Counter-state' or society, see House and MacMaster, Paris 1961, 61-6; Benjamin Stora, Ils Venaient d'Algérie. L'Immigration algérienne en France, 1912-1992 (Paris: Fayard, 1992), chapter 19.

68 FLN documents from the private archive of Mohammed Harbi, published in Sou'al, 7 (September 1987), 30, 36, 40, 45.

69 The Paris police archives, APP HA/53, SCINA Synthèses quotidiennes, 31 October to 2 November 1959, has the complete text of the Règlement; a further copy was sent to the Algiers government, located CAOM 18F122. Borrmans, Statut personnel, 499-501, note 106, reproduces the text, but gives no provenance for the document.

70 For a more detailed investigation of the changing position of Algerian women and the family in metropolitan France see Amelia H. Lyons, 'Invisible Immigrants: Algerian Families and the French Welfare State in the Era of Decolonization (1947-1974)', PhD thesis, University of California, Irvine, 2004; and for a later period, Caitlin Killian, North African Women in France. Gender, Culture, and Identity (Stanford, California: Stanford University Press, 2006).

71 APP HA/53, SCINA report, 31 October to 2 November, includes other FLN documents found with the Règlement which indicated ongoing surveys of the number of mixed marriages. Part of the concern about FLN militants having relationships with young European women was that the latter might be agents of French intelligence (DST).

72 The fullest treatment of the issue was given by the FLN militants 'Saadia-etLakhdar', L'Aliénation colonialiste, Part 4, 'Émigration et mariage mixte', 145-95, which presented the mixed marriage as a deliberate 'assimilationist' strategy of the colonial power to infiltrate and subvert the integrity of the Algerian family. The increase in the number of Algerian women in France was, they claimed, rectifying this situation and, in line with Fanon's thesis, enabling women to achieve a new revolutionary consciousness and role in the FLN French Federation. But once again this evolution was seen in terms of domestic support, for example undertaking shopping, usually done 
by men, so the latter had more time to devote to militant activities. For a later feminist opinion on mixed marriage see Fadéla M'Rabet, 'La Femme algérienne', suivi de 'Les Algériennes' (Paris: Maspero, 1983 edn), 42-6, 77-80.

73 Amrane-Minne, Des femmes, 171-7, interview with 'X'.

74 Commandant Azzedine, On nous appelait fellaghas, 297.

75 Courrière, La Guerre d'Algérie, Vol. 3, 103-4.

76 Commandant Azzedine, On nous appelait fellaghas, 252-3, the problem was resolved by the policy of placing husbands and wives in different units or areas.

77 Ibid., 282-3, 295.

78 SHAT 1H2582, minutes of Wilaya V, 2-7 October 1957, seized by the French army 19 November 1957.

79 Commandant Azzedine, On nous appelait fellaghas, 297.

80 Amrane-Minne, Des femmes, 52.

81 Amrane, Les Femmes algériennes, 250-1.

82 Amrane-Minne, Des femmes, 78.; see also Amrane, Les Femmes algériennes, 244-5.

83 Amrane, Les Femmes algériennes, 85-6.

84 Harbi and Meynier (eds), FLN: Documents, 614-5, directive Wilaya II, 15 December 1958.

85 Amrane-Minne, Des femmes, 91.

86 Launay, Paysans algériens, 351-2.

87 Hélène Vandevelde-Daillière, Malgré la tourmente. Récit - témoignage (La Ravoire: Éditions GAP, 1994), 249.

88 SHAT 1585/3*, Second Bureau intelligence fiche on Organisation féminine à l'extérieur, 1960-61. Nurses were trained, for example, in several locations in Morocco (Oudja, Larache, the hospitals of Kef and Souk-El-Arba, and by the youth Istqlal at Tetouan), and in Egypt at Alexandria.

89 Meynier, Histoire intérieure, 230.

90 SHAT 1585/3*; Borrmans, Statut personnel, 508. International solidarity was shown, for example, by the Ligue de la femme irakienne that sought permission from the Algerian provisional government (GPRA) for Iraqi women to engage in the ranks of the ALN; see also Seferdjeli, 'Fight With Us', 184-6 on conferences in Vietnam, Albania, Conakry, Bamako and elsewhere.

91 SHAT 1585/3*, SEDECE report, 31 May 1961. Rahal was secretary to the Bureau fédéral de l'Organisation Scouts Musulmane in Rabat.

92 Meynier, Histoire intérieure, 231.

93 See chapter 2 where the commander of the Operation Pilot had remarked as early as 24 February 1957, that 'The central idea [of Servier] must be the freeing of the masses from poverty and ignorance, and the liberation of women, aims that the FLN by its very nature cannot entertain', SHAT $1 \mathrm{H} 2536 / 2^{*}$. 
94 SHAT 1H1147/1, press cutting, Suddeutsche Zeitung (Munich), 21 February 1959; for a similar analysis see Serge Bromberger, Figaro 18 September 1958, 'Les Femmes musulmanes d'Algérie devant leur destin'.

95 SHAT 1H2461/1. Harbi and Meynier (eds), FLN: Documents, 609-12, which reprints this important document, identifies the location as in the region of Béchar, deep in the Sahara, close to the Moroccan border.

96 SHAT 1H2461/1, Fifth Bureau, Étude des 'Directives FLN', 12 February 1959.

97 SHAT 1H2461/1, Fifth Bureau to EMSI, 5 March 1959.

98 On the question of women's rights during nationalist struggle see Jayawardena, Feminism and Nationalism.

99 SHAT $1 \mathrm{H} 2582$.

100 SHAT 1H1669/1*, quoted by Meynier, Histoire intérieure, 230.

101 Minutes of the Soummam Conference, Courrière, La Guerre d'Algérie, Vol. 2, Appendix, 676.

102 Amrane, Les Femmes algériennes, 251-3.

103 Meynier, Histoire intérieure, 229.

104 Ibid., 229.

105 Amrane, Les Femmes algériennes, 253.

106 Ibid., 46.

107 See Shirin M. Rai, 'Gender, Nationalism and Nation-Building', in Gender and the Political Economy of Development (Cambridge: Polity, 2002); Chatterjee, 'Colonialism, Nationalism, and Colonized Women'.

108 Zerdoumi, Enfants d'hier, 38.

109 Fanon, L'An V, 19-20; see also Saadia-et-Lakhdar, L'Aliénation colonialiste, 151.

110 Ferhat Abbas, Autopsie d'une guerre (Paris: Garnier, 1980), 13-14. 